University of New Hampshire

University of New Hampshire Scholars' Repository

1994

\title{
An ice-core-based record of biomass burning in the Arctic and Subarctic, $1750-1980$
}

\author{
Sallie I. Whitlow \\ University of New Hampshire - Main Campus \\ Paul A. Mayewski \\ University of New Hampshire - Main Campus \\ Jack E. Dibb \\ University of New Hampshire, jack.dibb@unh.edu \\ Mark S. Twickler \\ University of New Hampshire - Main Campus \\ G Holdsworth \\ University of New Hampshire - Main Campus
}

Follow this and additional works at: https://scholars.unh.edu/earthsci_facpub

Part of the Atmospheric Sciences Commons

\section{Recommended Citation}

Whitlow, Sallie I.; Mayewski, Paul A.; Dibb, Jack E.; Twickler, Mark S.; and Holdsworth, G, "An ice-corebased record of biomass burning in the Arctic and Subarctic, 1750-1980" (1994). Tellus B. 44.

https://scholars.unh.edu/earthsci_facpub/44

This Article is brought to you for free and open access by the Earth Sciences at University of New Hampshire Scholars' Repository. It has been accepted for inclusion in Earth Sciences Scholarship by an authorized administrator of University of New Hampshire Scholars' Repository. For more information, please contact Scholarly.Communication@unh.edu. 


\title{
An ice-core-based record of biomass burning in the Arctic and Subarctic, 1750-1980
}

\author{
By S. WHITLOW*, P. MAYEWSKI, J. DIBB, G. HOLDSWORTH ${ }^{1}$ and M. TWICKLER, Glacier \\ Research Group, Institute for the Study of Earth, Oceans and Space, University of New Hampshire, \\ Durham, NH, USA; 'also at National Hydrology Research Institute, Saskatoon, Saskatchewan, and \\ Arctic Institute of North America, University of Calgary, Canada
}

(Manuscript received 17 June 1993; in final form 22 October 1993)

\begin{abstract}
Ammonium records from 3 ice cores, 20D and GISP2 (Greenland) and Mt. Logan (Yukon), covering the period from 1750 to the 1980 s are analyzed. For each data set, samples with $\mathrm{NH}_{4}^{+}$ concentrations greater than one standard deviation above the mean value also tend to be enriched in $\mathrm{NO}_{3}^{-}$and $\mathrm{K}^{+}$, similar to the chemical composition of aerosols from aged biomass burning plumes. We believe the $\mathrm{NH}_{4}^{+}$spikes originate from biomass burning events. There is not a one to one correspondence between documented large fires and $\mathrm{NH}_{4}^{+}$spikes, nor are specific annual layers with elevated $\mathrm{NH}_{4}^{+}$concentrations often found in more than one core. However, frequency of $\mathrm{NH}_{4}^{+}$spikes increase during periods of more extensive and intensive biomass burning in the $\mathrm{NH}_{4}^{+}$source areas for the ice core sites. The 20D and GISP2 records are characterized by increased spike frequency from 1790 to 1810 and from 1830 to 1910 . This latter time coincides with a period of increased biomass burning documented in the historical fire records for northern North America. In contrast to both Greenland ice core records, the Mt. Logan $\mathrm{NH}_{4}^{+}$record shows periods of increased spike frequency from 1770-1790, 1810-1830, 1850-1870 and 1930-1980. The poor agreement between the Mt. Logan record and the records from Greenland suggests that another source area, perhaps Siberia, may be the dominant summertime source area for $\mathrm{NH}_{4}^{+}$spikes in Mt. Logan snow.
\end{abstract}

\section{Introduction}

Ammonium concentration records from three high latitude ice cores were examined. Two of the core sites are located on the Greenland icecap, 20D $\left(65.01^{\circ} \mathrm{N}, 44.87^{\circ} \mathrm{W}, 2625 \mathrm{~m}\right.$ asl $)$, and GISP2 $\left(72.2^{\circ} \mathrm{N}, 37.80^{\circ} \mathrm{W}, 3200 \mathrm{~m}\right.$ asl). The $3 \mathrm{rd}$ site, Mt. Logan, in Yukon, Canada $\left(60.58^{\circ} \mathrm{N}, 140.58^{\circ} \mathrm{W}\right.$, $5346 \mathrm{~m}$ asl) is a very high altitude, subarctic site (Fig. 1). The ice core records studied cover the period from 1750 to the 1980 s.

The ammonia component of the nitrogen cycle has been studied intensely in recent years (e.g., Langford et al., 1992; Hegg et al., 1988; Stedman and Shetter, 1983). Ammonia is the dominant

\footnotetext{
* Corresponding author.
}

atmospheric gaseous base available for neutralizing $\mathrm{H}_{2} \mathrm{SO}_{4}$ and $\mathrm{HNO}_{3}$. Since both $\mathrm{H}_{2} \mathrm{SO}_{4}$ and $\mathrm{HNO}_{3}$ are increasing. due to anthropogenic activity, the role of $\mathrm{NH}_{3}$ is becoming more important. A recent review of $\mathrm{NH}_{3}$ sources and sinks concluded that continents are the dominant source of $\mathrm{NH}_{3}$ (Stedman and Shetter, 1983; Langford et al., 1992). Ammonia emissions are positively correlated to temperature, hence are highest in the summertime (LeBel et al., 1985; Langford et al., 1992).

A major impediment to $\mathrm{NH}_{3}$ and $\mathrm{NH}_{4}^{+}$ atmospheric studies has been the difficulty of accurately measuring ambient concentrations of either component (Langford et al., 1992; Griffith et al., 1991; Silvente and Legrand, 1993). The atmospheric lifetime of $\mathrm{NH}_{3}$ is relatively short in the boundary layer (a few days) due to rapid incor- 


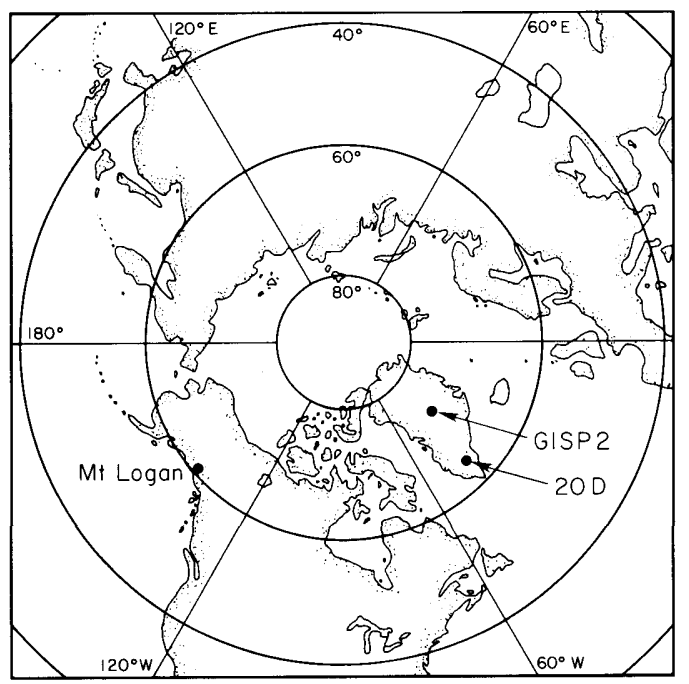

Fig. 1. Location map showing the ice core sites: Mt. Logan (ML) (Yukon), 20D and GISP2 (Greenland).

poration and removal in acidic aerosols, mineral dust aerosols or cloud water. The terrestrial surface source and the reactivity of $\mathrm{NH}_{3}$, combine to yield concentration profiles in the atmosphere which rapidly decrease with height. Most $\mathrm{NH}_{3}$ is returned to the surface as an $\mathrm{NH}_{4}^{+}$salt relatively near the initial source (LeBel et al., 1985; Langford et al., 1992). However, the fraction that does reach the free troposphere can be transported long distances (Langford et al., 1992).

Biomass burning is probably the dominant process which transports high concentrations of $\mathrm{NH}_{3}$ and $\mathrm{NH}_{4}^{+}$above the boundary layer. Turbulent mixing and convective columns associated with large fires can lift smoke to altitudes greater than $3 \mathrm{Km}$ (Radke et al., 1991; Andreae et al., 1988; Shipham et al., 1992). Recent studies suggest that biomass burning is the dominant source of $\mathrm{NH}_{4}^{+}$ for the free troposphere in the arctic and subarctic region of the Northern Hemisphere in the summertime (LeBel et al., 1991; Talbot et al., 1992). If this is true, the $\mathrm{NH}_{4}^{+}$spike records recovered from high latitude ice cores could provide records of biomass burning in the primary summertime aerosol source areas for the different coring sites. Ammonium records from 20D, Mt. Logan and GISP2 were compared to northern hemisphere biomass burning records to determine if the ice core records can provide a fire activity history.

\section{Methods}

Cores from 20D, Mt. Logan and GISP2 were collected and processed using stringent precautions and ultraclean procedures to minimize contamination (Mayewski et al., 1986; Holdsworth et al., 1988; Buck et al., 1992). The $115 \mathrm{~m} \mathrm{20D}$ and $103 \mathrm{~m} \mathrm{Mt}$. Logan cores were sampled at high resolution, averaging 6.3 and 6.4 samples $a^{-1}$, respectively, for the length of each core. GISP2 samples are approximately biannual, although some sections of the core were sampled at higher resolution (10 samples per year). The discontinuous detailed sections from the GISP2 core ( $25 \%$ of the top $80 \mathrm{~m}$ ) allowed the seasonality of the chemical species to be determined. Eight ions $\left(\mathrm{Na}^{+}, \mathrm{NH}_{4}^{+}, \mathrm{K}^{+}, \mathrm{Mg}^{2+}, \mathrm{Ca}^{2+}, \mathrm{Cl}^{-}, \mathrm{NO}_{3}^{-}\right.$, $\mathrm{SO}_{4}^{2-}$ ) were determined for each sample by suppressed ion chromatography using a $0.5 \mathrm{ml}$ sample loop in the Glacier Research Group laboratory (Buck et al., 1992).

Samples from Mt. Logan, GISP2 and the lower $37 \mathrm{~mm}$ of $20 \mathrm{D}$ (older than 1850) were run within $2 \mathrm{~h}$ of initial melting. Samples from the upper portion of the 20D core had been refrozen prior to $\mathrm{NH}_{4}^{+}$analysis. Ammonium values for these samples have been corrected by subtracting a procedural blank. Comparison of data from duplicate aliquots from the GISP2 core, one analyzed immediately and one refrozen prior to analysis, indicates higher $\mathrm{NH}_{4}^{+}$values for refrozen samples. The increase in $\mathrm{NH}_{4}^{+}$concentration in refrozen samples seems to be independent of the initial concentration and has never exceeded $5 \mu \mathrm{g}^{-1}$ (Unpub. data, GRG). Based on this, refreezing could not cause the large $\mathrm{NH}_{4}^{+}$spikes in the $20 \mathrm{D}$ data which are the focus of this paper.

All three cores were dated by multiple techniques. Annual oscillations in $\delta^{18} \mathrm{O}$, soluble ionic chemistry, and correlation of $\mathrm{SO}_{4}^{2-}$ spikes to known volcanic eruptions were used to date the 20D and Mt. Logan cores (Holdsworth et al., 1984, 1991; Mayewski et al., 1986, 1993a). The dating produced annually resolved chronologies back to 1688 at Mt. Logan and 1769 at 20D. The GISP2 core was dated utilizing a combination of 
physical stratigraphy, $\delta^{18} \mathrm{O}, \mathrm{ECM}$ (electrical conductivity measurement), dust, and chemistry as described in Meese et al. (in press).

\section{Results}

The detailed records from 20D and Mt. Logan are both characterized by $\mathrm{NH}_{4}^{+}$spikes superim- posed on a relatively uniform, low background (Fig. 2). Median values for the three sites are very similar (Table 1). Inspection of the detailed profiles from all three cores shows that the maximum $\mathrm{NH}_{4}^{+}$concentrations occur in "summertime" snow and minimum concentrations in "wintertime" snow. (Summer and winter are defined in reference to the $\delta^{18} \mathrm{O}$ profiles). In addition, some years are characterized by unusual large $\mathrm{NH}_{4}^{+}$
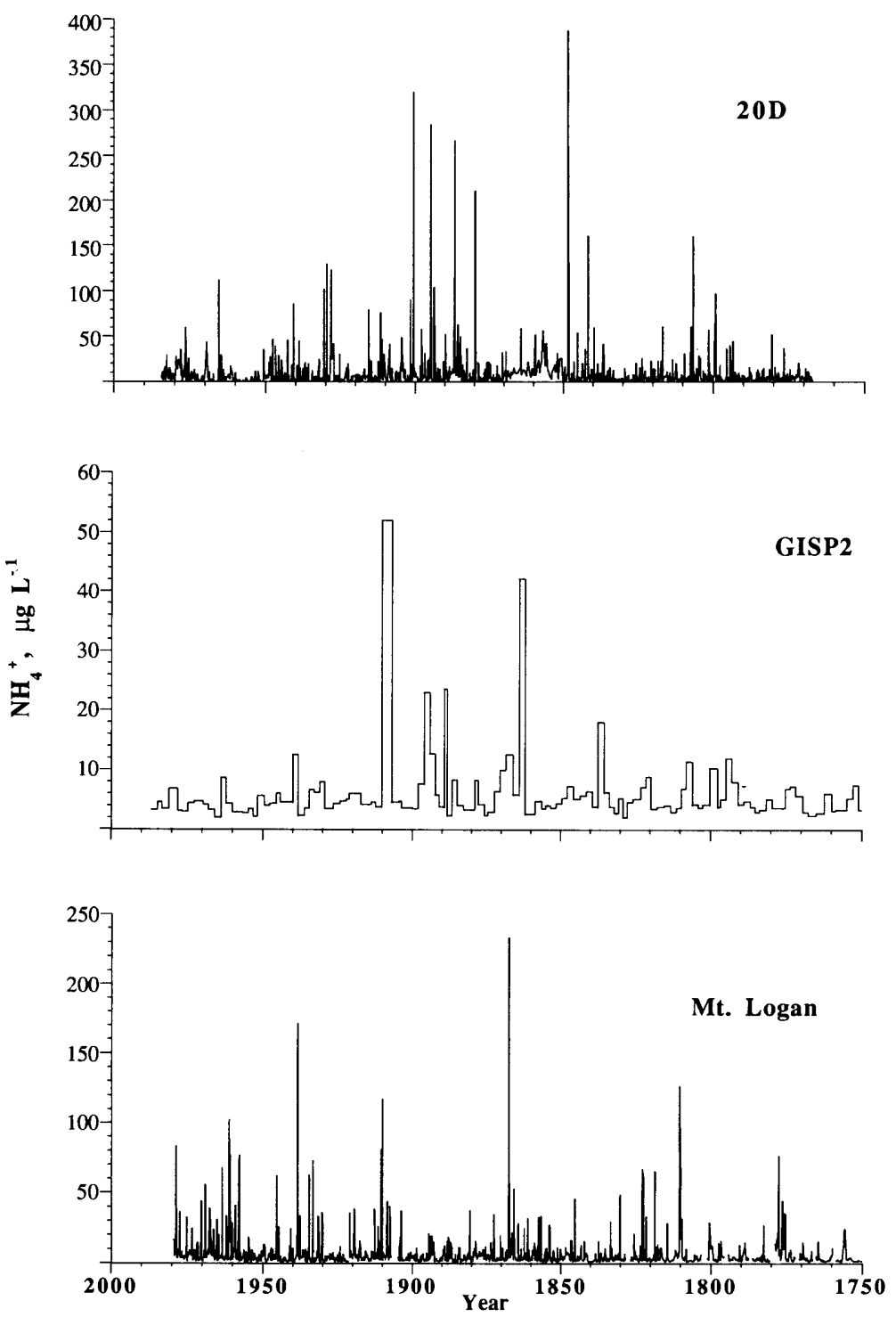

Fig. 2. Detailed records from 20D, GISP2 and Mt. Logan; concentrations ( $\left.\mu \mathrm{g} \mathrm{l}^{-1}\right)$. 
spikes which consist of one or two "summertime" samples with concentrations that are at least a factor of 5 greater than the maximum summertime $\mathrm{NH}_{4}^{+}$concentration of neighboring years (Fig. 3 ). These unusual spikes are the events of interest.

Annual averages were calculated from the 20D and Mt. Logan detailed data to generate a data set with no seasonal $\mathrm{NH}_{4}^{+}$signal. These derived data sets and the bi-yearly GISP 2 data are also characterized by $\mathrm{NH}_{4}^{+}$spikes, defined as $\mathrm{NH}_{4}^{+}$values greater than the mean plus one standard deviation
(Table 1, Fig. 4). All the unusual $\mathrm{NH}^{4+}$ events in the 20D and Mt. Logan detailed records survived averaging over annual intervals and still appear as spikes in the smoothed record.

$75 \%$ of the $20 \mathrm{D} \mathrm{NH}_{4}^{+}$spikes and $70 \%$ of the GISP2 $\mathrm{NH}_{4}^{+}$spikes are concentrated in the interval from 1830 to 1910 . (The GISP2 record shows lower spike concentrations due to the 2-year sampling resolution.) The period from 1790 to 1810 at both sites is also characterized by 2 spikes (Fig. 4). The similarity in the records at 20D and
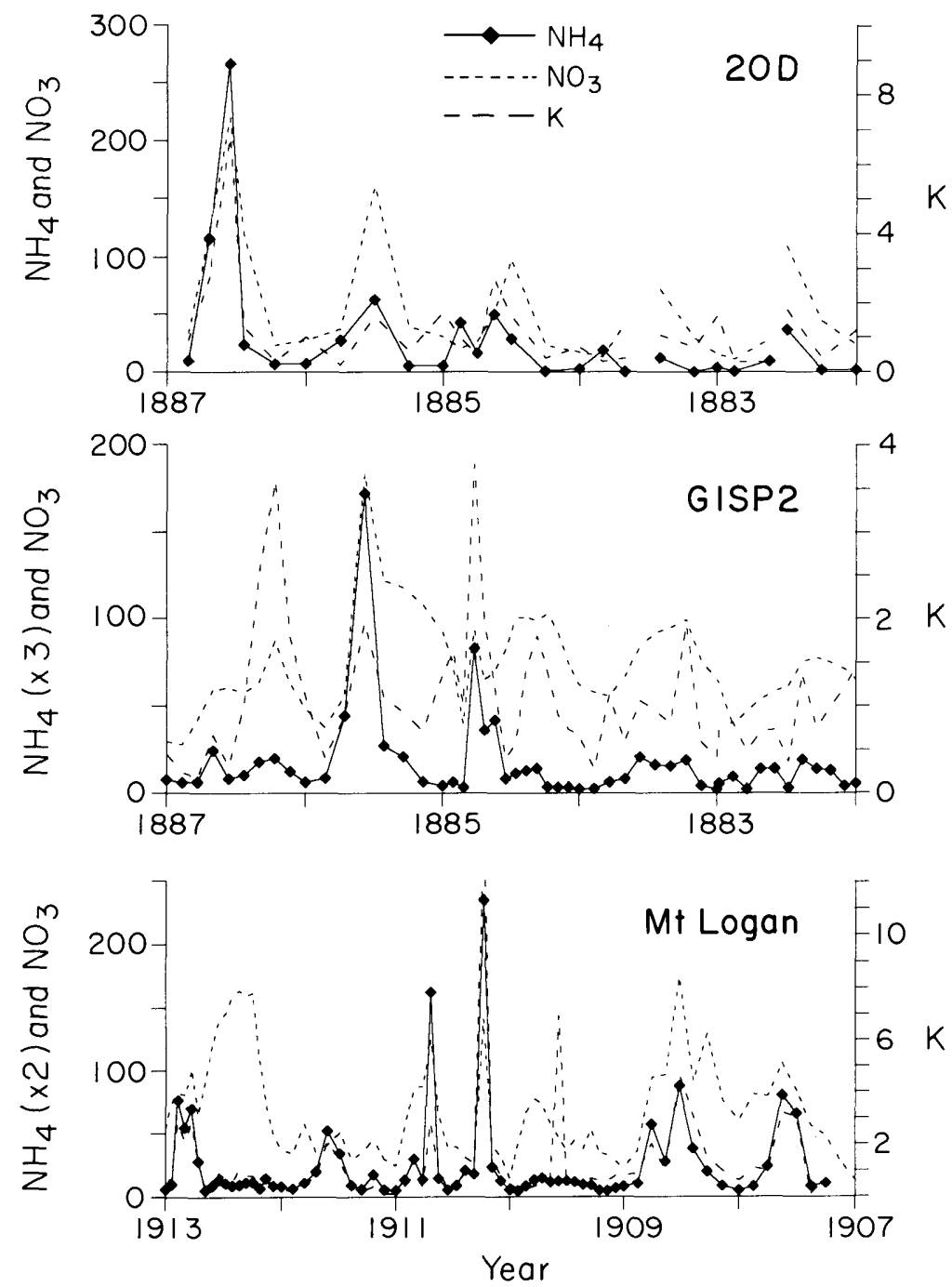

Fig. 3. Plots of detailed $\mathrm{NH}_{4}^{+}, \mathrm{K}^{+}$, and $\mathrm{NO}_{3}^{-}$data over 5-year intervals from 20D, GISP2 and Mt. Logan; concentrations $\left(\mu \mathrm{g} \mathrm{l}^{-1}\right)$. 
GISP2 is encouraging because the 2 sites are near the crest of the Greenland ice sheet, separated by $8^{\circ}$ of latitude. This similarity suggests that they have common summertime aerosol source areas.

Ammonia spikes in the $\mathrm{Mt}$. Logan record are present in the intervals 1770-1790, 1810-1830, 1850-1870, and 1930-1980 (Fig. 4). $68 \%$ of the $\mathrm{NH}_{4}^{+}$spikes in the Mt. Logan record occur in the
Table 1. Summary statistics for $\mathrm{NH}_{4}^{+}$concentrations, $\mu \mathrm{g}^{-1}$, based on yearly averages

\begin{tabular}{llcl}
\hline Site & Mean & $\sigma$ & Median \\
\hline Mt. Logan & 6.9 & 6.74 & 3.5 \\
20-D & 9.31 & 11.83 & 3.52 \\
GISP & 5.89 & 5.2 & 4.24 \\
\hline
\end{tabular}
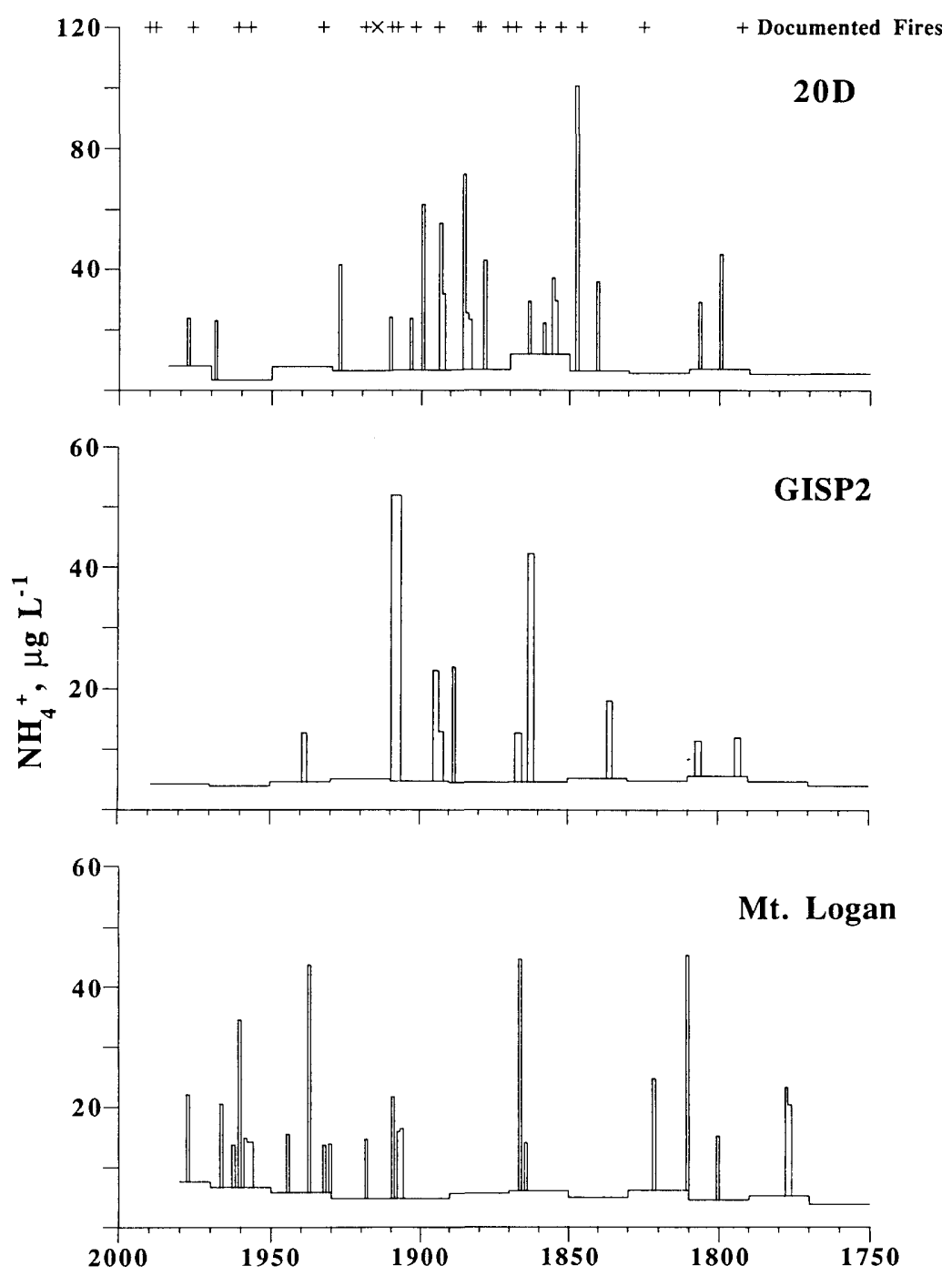

Fig. 4. Plot of $\mathrm{NH}_{4}^{+}$spikes ( $>$mean $+1 \sigma$ ) for 20D, GISP2, and Mt. Logan. The baseline $\mathrm{NH}_{4}^{+}$values plotted with the spikes are 20-year averages calculated without the years with spikes. Years with large $(>500,000$ acres $)$ fires in northern North America $(+)$ and Siberia $(x)$ are indicated above the 20D plot. 
interval 1900 to 1980 , when few are seen in Greenland. The dissimilarity in the timing of the $\mathrm{NH}_{4}^{+}$spikes between $\mathrm{Mt}$. Logan and the 2 Greenland sites strongly suggests that the ice core records from the 2 areas are recording events from different $\mathrm{NH}_{4}^{+}$source areas.

\section{Discussion}

The large $\mathrm{NH}_{4}^{+}$spikes observed in the ice cores from the three sites are similar to the large, short duration $\mathrm{NH}_{4}^{+}$spikes that have been documented in summer layers in the GRIP ice core from Summit (Legrand et al., 1992). The GRIP samples with elevated $\mathrm{NH}_{4}^{+}$concentrations also had enhanced concentrations of organic acids, especially formate (Legrand et al., 1992). Elevated concentrations of $\mathrm{NH}_{4}^{+}$and organic acids characterize aged biomass burning plumes in the free troposphere (Andreae et al., 1988; Talbot et al., 1992), leading Legrand et al. (1992) to hypothesize that the layers in the GRIP core represent biomass burning events. Organic acids were not analyzed in samples from the three sites discussed here. However, other characteristics of the soluble ion chemistry in the samples with enhanced $\mathrm{NH}_{4}^{+}$concentrations also suggest a biomass burning source.

In addition to higher $\mathrm{NH}_{4}^{+}$and organic acid concentrations, aerosols in aged biomass burning plumes contain elevated concentrations of $\mathrm{K}^{+}$, $\mathrm{NO}_{3}^{-}$, and $\mathrm{SO}_{4}^{2-}$ (Andreae et al., 1988; Talbot et al., 1992). When the large $\mathrm{NH}_{4}^{+}$spikes from the 3 ice core records are examined at subseasonal resolution; $\mathrm{K}^{+}$and $\mathrm{NO}_{3}^{-}$concentrations tend to increase in the same samples with higher $\mathrm{NH}_{4}^{+}$concentrations (Fig. 3). Chemical similarity between the composition of the ice core $\mathrm{NH}_{4}^{+}$ spikes and aerosol enrichments observed in aged biomass burning plumes suggests that the ice core $\mathrm{NH}_{4}^{+}$spikes record biomass burning events.

General west to east circulation in the upper troposphere at the latitudes of the three ice core sites suggests that northern North America is probably the dominant source area for Greenland and Siberia is a likely source for Mt. Logan (Davidson et al., 1993; Holdsworth et al., 1992). These two areas, Canada and Siberia, are the dominant biomass burning source areas of all the circumpolar countries, with estimated annual burn areas of over 3 million acres in Siberia and over
2 million acres in Canada (Stocks, 1991). Minor inputs to Greenland from Europe and Siberia are also possible due to disruptions in the zonal flow (Davidson et al., 1993). Additional possible source regions impacting Mt. Logan include the neighboring areas of Alaska and British Columbia. Satellite imagery and aircraft sampling have shown that forest fire plumes travel quickly and maintain their visual and chemical identity for at least several days (Robock, 1991; Westphal and Toon, 1991; Ferrare et al., 1990; Talbot et al., 1992; Wofsy et al., 1992); therefore, $\mathrm{NH}_{4}^{+}$spikes source areas do not have to be in close proximity to the core sites.

The unusual high $\mathrm{NH}_{4}^{+}$spikes preserved in the ice core record are the result of a progression of special events: (1) a large, very intense fire (minimum size is not known) must occur in the source area and generate a $\mathrm{NH}_{3} / \mathrm{NH}_{4}^{+}$rich plume that is lofted rapidly to the free troposphere; $(2)$ wind trajectories must transport the plume quickly to the core site; (3) dilution/dispersion or scavenging of the plume enroute must be minimal; (4) the aerosols in the plume must be deposited and preserved at the ice core site. These special events mean that an ice core record will preserve only a small fraction of large biomass burning events that occur in its summertime source area. However, the number of spikes preserved per unit time should reflect the relative frequency of fires in the source area.

The $\mathrm{NH}_{4}^{+}$spike records from 20D and GISP2 were compared to the fire record for northern North America. Unfortunately, very poor to no historical fire records exist for northern Canada or Alaska prior to the early 1900 s (since historical records are biased toward populated areas). Fig. 4 shows 20 documented intense fires ( $>500,000$ acres burned) which occurred in North America since 1750 and a large Siberian fire in 1915 (Plummer, 1912; Pyne, 1982; Fuller, 1991). As there are no historical or recent fire records for Siberia, probably the dominant source region for $\mathrm{Mt}$. Logan (see below), a similar comparison is not possible.

The sparsity of spikes since 1910 in both Greenland records suggest low biomass burning activity in the source area (Table 2, Fig. 4). This concides with the beginning of active fire suppression in 1910 in northern North America which resulted in a decrease in fire activity (Van Wagner, 
Table 2. Number of individual years with spikes for each 20-year interval for 20D, Mt. Logan and GISP2; ccd-core drill date 1989-GISP2; 1984 20D; and 1980-Mt. Logan

\begin{tabular}{lccc}
\hline Time & \multicolumn{3}{c}{ Number of Spikes } \\
\hline & $20 \mathrm{D}$ & GISP2 & Mt. Logan \\
$1750-1769$ & 0 & 0 & 0 \\
$1770-1789$ & 0 & 0 & 2 \\
$1790-1809$ & 2 & 2 & 1 \\
$1810-1829$ & 0 & 0 & 2 \\
$1830-1849$ & 2 & 1 & 0 \\
$1850-1869$ & 4 & 2 & 2 \\
$1870-1889$ & 5 & 1 & 0 \\
$1890-1909$ & 4 & 3 & 2 \\
$1910-1929$ & 2 & 0 & 2 \\
$1930-1949$ & 0 & 1 & 4 \\
$1950-1969$ & 1 & 0 & 6 \\
$1970-$ cdd & 1 & 0 & 1 \\
\hline
\end{tabular}

1988; Stocks, 1991). Anthropogenic acidification of the northern hemisphere atmosphere since 1900, which is recorded in Greenland snow by increasing $\mathrm{SO}_{4}^{2-}$ and $\mathrm{NO}_{3}^{-}$concentrations (Mayewski et al., 1993a) may be accentuating the decrease through production of ammonium aerosols which are largely scavenged before reaching Greenland (Stedman and Shetter, 1983; Legrand et al., 1992). The most recent $\mathrm{NH}_{4}^{+}$spikes at 20D may reflect the increase in total number of acres burned in North America since the seventies (Van Wagner, 1988; Fuller, 1991; Stocks, 1991 ).

Although quantitative data about forest fires prior to 1920 does not exist, historical accounts and analysis of tree fire scars indicate that there were numerous, large, extensive forest fires during the 1800s and early 1900s in northern North America (Plummer, 1912; Williams, 1989; Pyne, 1982; Leavitt, 1991; Suffling, 1991; Alexander, 1980; Johnson, 1980; Tande, 1980; Payette, 1980). This period of greater biomass burning is reflected in the 20D and GISP2 $\mathrm{NH}_{4}^{+}$records by the high number of $\mathrm{NH}_{4}^{+}$spikes during the $1830-1900$ period (Fig. 4).

The Mt. Logan $\mathrm{NH}_{4}^{+}$spikes do not coincide with spikes in the two Greenland records. This agrees with the earlier observation that North America is not a dominant source region for air over Mt. Logan (Holdsworth et al., 1991; Mayewski et al., 1993a). Central and eastern
Siberia are possible source areas; plumes from the 1987 fire in central Siberia were observed in satellite images over Alaska (Robock, 1991). In addition, aged biomass burning plumes from Siberia were sampled over Alaska during ABLE 3A (Shipham et al., 1992; Wofsy et al., 1992). The Mt. Logan $\mathrm{NH}_{4}^{+}$spike record suggests there have been 4 periods of higher biomass burning in the source area, 1770-1790, 1810-1830, 1850-1870 and 1930-1980. The decreasing frequency of intense forest fires in Alaska and Canada since 1920 and the increasing frequency of $\mathrm{NH}_{4}^{+}$spikes in the Mt. Logan data, suggests that local biomass burning is of minor importance to this record.

If as suggested above, the $\mathrm{NH}_{4}^{+}$spike frequency record preserves a generalized biomass burning record of the summertime source area, this record may also be used as a general indicator of the existence of climatic conditions conducive to biomass burning. The North American record since 1920 has been dominated by fire suppression and fire control which probably has modified forest fire response to climatic factors. The recent increase in North American fires is thought to be climate driven, corresponding to dry summer weather (Suffling, 1991; Fuller, 1991; Stocks, 1991; Schindler et al., 1990). Current biomass burning response may be enhanced due to the tinder accumulated during the preceeding decades of fire suppression. It has also been suggested that the North American fires in the 1800 s were largely climate driven, the number of fires increasing during droughts (Suffling, 1991; Tande, 1980; Alexander, 1980; Schindler et al., 1990; Payette, 1980). The mid to late 1800 s is considered to be the end of the Little Ice Age (Lamb, 1982; Mayewski et al., 1993b). Fire intensity and frequency in the 1800 s was amplified by extensive burning to clear land for agriculture as the North American populus rapidly expanded westward (Pyne, 1982). In addition, logging practices of that era left much waste behind which served as fire fuel, and sparks from the railroad increased the possibility of ignition (Plummer, 1912; Leavitt, 1991; Williams, 1989; Tande, 1980).

If as suggested by Stocks (1991), most of the fires in Siberia are caused by lightning (due to the remoteness and low population density of the area), the record from Mt. Logan may be a better example of the climate-forest fire relationship that could be used with longer ice core records. 


\section{Conclusions}

Correspondence between the biomass burning history of northern North America since the $1800 \mathrm{~s}$ and $\mathrm{NH}_{4}^{+}$spike records from 20D and GISP2 suggests that these ice cores at least qualitatively record the frequency of intense, large biomass burning in northern North America. It may be possible to extend the relationship further based on the general coincidence between dry summer conditions and increased fire intensity and activity (Van Wagner, 1988). This suggests that the intervals characterized by a high frequency of $\mathrm{NH}_{4}^{+}$ spikes may also correspond to periods of dry summer weather in the source area.

The difference between the $\mathrm{NH}_{4}^{+}$spike record from Mt. Logan and the two records from Greenland suggests that Siberia and northern North America have very different biomass burning histories. The $\mathrm{NH}_{4}^{+}$record from Mt. Logan suggests that Siberia has experienced an increase in intense, extensive biomass burning since the late
1800 s. The average $\mathrm{NH}_{4}^{+}$values from 1930 to 1970 are the highest in the 230 year record, and also represent the longest time period of high average $\mathrm{NH}_{4}^{+}$values.

\section{Acknowledgements}

We thank M. J. Spencer and C. Buck for assisting with many of the chemical analyses on samples from all cores. The assistance of the Polar Ice Coring Office in the recovery of the 20D core and the GISP2 core and the assistance of GISP2 SMO is gratefully acknowledged. G. H. thanks personnel of the Arctic Institute of North America, University of Calgary, for their assistance and support. Support for this reseach was provided by the Electric Power Research Institute, the US Environmental Protection Agency, US National Science Foundation Division of Polar Programs and Environment Canada.

\section{REFERENCES}

Andreae, M. O., Browell, E. V., Garstung, M., Gregory, G. L., Harriss, R. C., Hill, G. F., Jacob, D. J., Pereira, M. C., Sachse, G. W., Setzer, A. W., Silva Dias, P. L., Talbot, R. W., Torres, A. L. and Wofsey, S. C. 1988. Biomass-burning emissions and associated haze layers over Amazonia. J. Geophys. Res. 93, 1509-1527.

Alexander, M. E. 1980. Forest fire history research in Ontario: a problem analysis. In: Proceedings of the Fire history Workshop, 20-24 October 1980. USDA Forest Service Technical Report RM-81, 96-109.

Buck, C. F., Mayewski, P. A., Spencer, M. J., Whitlow, S., Twickler, M. S. and Barrett, D. 1992. Determination of major ions in snow and ice cores by ion chromatography. J. of Chrom. 594, 225-228.

Davidson, C. I., Jaffrezo, J.-L., Small, M. J., Summers, P. W., Olson, M. P. and Borys, R. D. 1993. Trajectory analysis of source regions influencing the south Greenland ice sheet during the DYE3 gas and aerosol sampling program. Atmos. Environ. 27A, 2739-2749.

Ferrare, R. A., Fraser, R. S. and Kaufman, Y. J. 1990. Satellite measurements of large-scale air pollution: measurements of forest fire smoke. J. Geophys. Res. 95, 9911-9925.

Fuller, M. 1991. Forest fires: an introduction to wildland fire behavior, management, firefighting and prevention. John Wiley and Sons, Inc., New York, NY.

Griffith, D. W., Mankin, W. G, Coffey, M. T., Ward, D. E. and Riebau A. 1991. FTIIR remote sensing of biomass burning emissions of $\mathrm{CO}_{2}, \mathrm{COCH}_{4}, \mathrm{CH}_{2} \mathrm{O}$, $\mathrm{NO}, \mathrm{NO}_{2}, \mathrm{NH}_{3}$ and $\mathrm{N}_{2} \mathrm{O}$. In: Global biomass burning (ed. J. L. Levine). MIT Press, Cambridge, Mass., 231-239.

Hegg, D. A., Radke, L. F. and Hobbs, P. V. 1988. Ammonia emissions from biomass burning. Geophys. Res. Lett. 15, 335-337.

Holdsworth, G., Pourchet, M., Prantl, F. A. and Meyerhof, D. P. 1984. Radioactivity levels in a firn core from the Yukon Territory, Canada. Atmos. Environ. 18, 461-466.

Holdsworth, G., Krouse, H. R. and Peake, E. 1988. Trace-acid ion content of shallow snow and ice cores from mountain sites in western Canada. Annals Glaciol. 10, 57-62.

Holdsworth, G., Fogarasi, S. and Krouse, H. R. 1991. Variation of the stable isotopes of water with altitude in the Saint Elias Mountains of Canada. J. Geophys. Res. 96, 7483-8494.

Holdsworth, G., Krouse, H. R. and Nosal, M. 1992. Ice core climate signals from Mount Logan, Yukon A.D. 1700-1987. In: Climate since $A D 1500$ (ed. R. S. Bradley and P. D. Jones). Routledge, New York, NY, 483-504.

Johnson, E. A. 1980. Fire recurrence and vegetation in the lichen woodlands of the Northwest Territories, Canada. In: Proceedings of the fire history Workshop, 20-24 October 1980. USDA Forest Service Gen. Tech. Rep. RM-81, 110-114.

Lamb, H. H. 1982. Climate history and the modern world. Methuen, New York, NY.

Langford, A. O., Fehsenfeld, F. C., Zachariassen, J. and 
Schimel, D. S. 1992. Gaseous ammonia fluxes and background concentrations in terrestrial ecosystems of the United States. Global Biogeochem. Cycles 6, 459-483.

Leavitt, S. W. 1991. The Great Lakes forest fires of 8-10 October 1871. In: Global biomass burning (ed. J. S. Levine). MIT Press, Cambridge, Mass., 519-522.

LeBel, P. J., Hoell, J. M., Levine, J. S. and Vay, S. A. 1985. Aircraft measurements of ammonia and nitric acid in the lower troposphere. Geophys. Res. Leti. 12, 401-404.

LeBel, P. J., Vay, S. A. and Roberts, P. D. 1991. Ammonia and nitric acid emissions from wetlands and boresl forest fires. In: Global biomass burning (ed. J. S. Levine). Cambridge, Mass., MIT Press, 225-229.

Legrand, M., DeAngelis, M., Staffelbach, T., Neftel, A. and Stauffer, B. 1992. Large perturbations of ammonium and organic acids content in the Summit Greenland ice core, fingerprint from forest fires? Geophys. Res. Lett. 19, 473-475.

Mayewski, P. A., Lyons, W. B., Spencer, M. J., Twickler, M., Dansgaard, W., Koci, B., Davidson, C. I. and Honrath, R. E. 1986. Sulfate and nitrate concentrations from a south Greenland ice core. Science 232, 975-977.

Mayewski, P. A., Holdsworth, G., Spencer, M. J., Whitlow, S., Twickler, M., Morrison, M. C., Ferland, K. K. and Meeker, L. D. 1993a. Ice core sulfate from three Northern Hemisphere sites: Source and temperature forcing implications. Atmos. Environ. 27A, 2915-2919.

Mayewski, P. A., Meeker, L. D., Morrison, M. C., Twickler, M. S., Whitlow, S. I., Ferland, K. K., Meese, D. A., Legrand, M. R. and Steffensen, J. P. 1993b. Greenland ice core "signal" characteristics: An expanded view of climate change. J. Geophys. Res. 98, 12839-12847.

Meese, D., Alley, R., Fiacco, J., Gow, A., Grootes, P., Germani, M., Illing, M., Mayewski, P., Morrison, M., Ram, M., Taylor, K., White, J., Yang, C. and Zielinski, G. Time-scale and accumulation profile to $719 \mathrm{~m}$ of the GISP2 ice core. US Army Cold Reg. Res. Eng. Lab. Rep., in press.

Payette, S. 1980. Fire history at the treeline in northern Quebec: a paleoclimatic tool. In: Proceedings of fire history Workshop, 20-24 October 1980. USDA Forest Service Gen. Tech. Rep. RM-81, 126-131.

Plummer, F. G. 1912. Forest fires: their causes, extent and effects, with a summary of recorded destruction and loss. USDA Forest Service Bull. 117, 5-39.

Pyne, S. J. 1982. Fire in America: a cultural history of wildland and rural fire. Princeton University Press, Princeton, NJ.

Radke, L. F., Hegg, D. A., Hobbs, P. V., Nance, J. D., Lyons, J. H., Laursen, K. K., Weiss, R. E., Riggan, P. J. and Ward, D. E. 1991. Particulate and trace gas emissions from large biomass fires in North America. In: Global biomass burning (ed. J. S. Levine). MIT Press, Cambridge, Mass., 209-224.
Robock, A. 1991. Surface cooling due to smoke from biomass burning. In: Global biomass burning (ed. J. S. Levine). MIT Press, Cambridge, Mass., 463-476.

Schindler, D. W., Beaty, K. G., Fee, E. J., Cruikshank, D. R., DeBruyn, E. R., Findlay, D. L., Linsey, G. A., Shearer, J. A., Stainton, M. P. and Turner, M. A. 1990. Effects of climatic warming on lakes of the central boreal forest. Science 250, 967-970.

Shipham, M. C., Bachmeier, A. S., Cahoon, D. R., Jr. and Browell, E. V. 1992. Meteorological overview of the Arctic Boundary Layer Expedition (ABLE 3A) flight series. J. Geophys. Res. 97, 16395-16420.

Silvente, E. and Legrand, M. 1993. Ammonium to sulphate ratio in aerosol and snow of Greenland and Antarctic regions. Geophys. Res. Lett. 20, 687-690.

Stedman, D. H. and Shetter, R. E. 1983. The global budget of atmospheric nitrogen species. In: Trace atmospheric constituents: properties, transformations and fates. John Wiley, New York, NY, 411-431.

Stocks, B. J. 1991. The extent and impact of forest fires in northern circumpolar countries. In: Global biomass burning (ed. J. S. Levine). Cambridge, Mass., MIT Press, 197-202.

Suffling, R. 1991. Wildland fire management and landscape diversity in the boreal forest of northwestern Ontario during an era of climatic warming. In: Fire and the environment: ecological and cultural prespectives: Proceedings of an International Symposium (ed. S. C. Nodvin and T. A. Waldrop). USDA Forest Service Gen. Tech. Rep. SE-69, 97-106.

Talbot, R. W., Vijgen, A. S. and Harriss, R. C. 1992. Soluble species in the arctic summer troposphere: acidic gases, aerosols and precipitation. J. Geophys. Res. 97, 16531-16544.

Tande, G. F. 1980. Interpreting fire history in Jasper National Park, Alberta. In: Proceedings of fire history Workshop, 20-24 October 1980. USDA Forest Service Gen. Tech. Rep. RM-81, 31-34.

Van Wagner, C. E. 1988. The historical pattern of annual burned area in Canada. The Forestry Chron., June, 182-185.

Westphal, D. L. and Toon, O. B. 1991. simulations of microphysical, radiative, and dynamical process in a continental-scale forest fire smoke plume. J. Geophys. Res. 96, 22379-22400.

Williams, M. 1989. Americans and their forests a historical geography. Cambridge Univ. Press, New York, NY, USA.

Wofsy, S. C., Sachse, G. W., Gregory, G. L., Blake, D. R., Bradshaw, J. D., Sandholm, S. T., Singh, H. B., Barrick, J. A., Harriss, R. C., Talbot, R. C., Shipham, M. A., Browell, E. V., Jacob, D. J. and Logan, J. A. 1992. Atmospheric chemistry in the arctic and subarctic: influence of natural fires, industrial emissions and stratospheric inputs. J. Geophys. Res. 97, 16731-16746. 